\begin{tabular}{|c|c|c|}
\hline Beitr. Ent. & Keltern & ISSN 0005-805X \\
\hline $\mathbf{5 1}(2001) 1$ & S. $51-63$ & 14.09 .2001 \\
\hline
\end{tabular}

\title{
A remarkable Dominican amber species of Cylindromyrmex with Brazilian affinities and additions to the generic revision
}

\author{
(Hymenoptera: Formicidae)
}

With 7 figures

\author{
MARIA L. DE ANDRADE
}

\section{Summary}

Cylindromymex inopinatus $\mathrm{n}$. $\mathrm{sp}$. from Dominican amber is described on two winged gynes. The new amber species appears to be the sister species of the Recent Brazilian longiceps. C. inopinatus and C. Longiceps can be easily distinguished from all other members of the genus by the head about $1 / 3$ longer than broad and by the narrowest known frontal carinae. C. inopinatus is the third amber fossil species of the genus as compared with 10 known extant species. The previously unknown male of C. longiceps ANDRÉ is also described. Additional distribution data are given for the species brasiliensis, brevitarsus, escobari, godmani, longiceps, meinerti and whymperi. The identification key to the males of DE ANDRADE (1998) is partially re-worked in order to include longiceps.

\section{Zusammenfassung}

Nach zwei geflügelten Gynen aus Dominikanischem Bernstein wird Cylindromyrmex inopinatus sp. n. beschrieben. Die neue fossile Art scheint die Schwesterart der rezenten C. longiceps aus Brasilien zu sein. C. inopinatus und C. longiceps unterscheiden sich von allen anderen Arten der Gattung durch einen besonders langgestreckten Kopf, der etwa ein Drittel länger als breit ist, und durch einen schmaleren Abstand zwischen den Stirnleisten. Mit C. inopinatus sind nunmehr drei fossile Arten aus Bernstein bekannt, denen zehn rezente Arten gegenüberstehen. Das bislang unbekannte Männchen von C. longiceps ANDRÉ wird beschrieben, und es werden zusätzliche Daten zur Verbreitung von C. brasiliensis, brevitarsus, escobari, godmani, longiceps, meinerti und whymperi genannt. Der Bestimmungsschlüssel für die Männchen von Cylizddromyrmex (DE ANDRADE 1998) wurde zur Einfügung von C. longiceps teilweise überarbeitet.

\section{Introduction}

The genus Cylindromyrmex was recently revised by DE ANDRADE (1998). In her revision, DE ANDRADE (1. c.) recognises 12 species of Cylindromyrmex, of which two, C. antillanus and $C$. electrinus are represent by fossil Dominican specimens based each on a single gyne. The opportunity to study new, additional material including a new fossil species, a previously undescribed male and some significant new locality records justifies the publication of the present update. 


\section{Material and Methods}

The following two Cylindromyrmex specimens in two samples of amber from the Dominican Republic from the collection of Dr. George O. Poinar Jr. (Department of Entomology, Oregon State University, Corvallis, U.S.A.) were examined:

H 10-138 B (Fig. 1). A small $(0.7 \times 0.5 \mathrm{~cm})$ yellow sample containing a winged gyne of Cylindromyrmex without gaster. The preservation conditions of the remaining specimen are very good .

H 10-138 C (Fig. 2). A light yellow sample $(1.0 \times 1.5 \mathrm{~cm})$ containing only one winged gyne of Cylindromyrmex. The preservation conditions of the specimen are good, though fissures rend difficult the examination of some body parts.

The recent specimens of Cylindromymex examined in this study otiginate from the following collections:

CEPLAC: Centro de Pesquisa do Cacau, Itabuna, Bahia, Brazil. Courtesy of Dr. Jacques H. C. Delabie. INBC: Instituto Nacional de Biodiversidad, San José, Costa Rica. Courtesy of Dr. John T. Longino.

MZSP: Museu de Zoologia da Universidade de São Paulo, Brazil. Courtesy of Prof. Dr. Carlos Roberto Ferreira Brandão.

MEUV: Museo de Entomologia de la Universidad del Valle. Cortesy of Dr. Patricia Chacón and Fabio Herney Lozano.

Measurements and indices are as described by DE ANDRADE (1998) for this genus.

Results

Cylindromyrmex inopinatus DE ANDRADE sp. n.

Figs. 1, 2 \& 3

Holotype: winged gyne in the amber sample $\mathrm{H} 10-138 \mathrm{C}$ from the GOPC.

Paratype: winged gyne (with missing gaster) in the amber sample $\mathrm{H} 10-138 \mathrm{~B}$, same collection as the holotype.

Derivatio nominis: From the Latin inopinatus (= unexpected).

\section{Diagnosis}

Inopinatus is the sister species of longiceps from which it differs for the total length smaller than $7 \mathrm{~mm}$ instead of larger than $7.4 \mathrm{~mm}$ and for the hypostomal bridge not reaching the postocciput instead of the hypostomal bridge broadly connected to the postocciput.

\section{Description}

Head about $1 / 3$ longer than broad and with parallel sides. Vertex low. Vertexal angles round and protruding backwards. Distance between the frontal carinae about $1 / 4$ of the maximum head width. Anterior third of the frontal carinae diverging backwards, remaining two thirds parallel and surpassing the anterior border of the eyes posteriorly. Dorsum of the frontal carinae with a median sulcus anteriorly. Frontal carinae shorter than the anterior border of the clypeus. Clypeus convex laterally and concave medially, its antero-median border with an irregular, minute denticle superficially bicatinate dorsally. Compound eyes very large, flat and on the middle of the dorsolateral part of the head; ocelli well defined. Scapes stout and not reaching the end of the frontal carinae posteriorly. Anterior fourth of the scapes about half as broad as the distal part. Mandibles short and flat dorsally. Masticatory margin of 
the mandibles with a small basal tooth followed by a denticle, an edentate margin and a pointed apical tooth. Hypostomal bridge broad, the anterolateral border convex, the posteromedial border broad anteriorly and strongly narrowing posteriorly.

Mesosoma weakly convex in side view. Pronotum and mesonotum subequal in size.
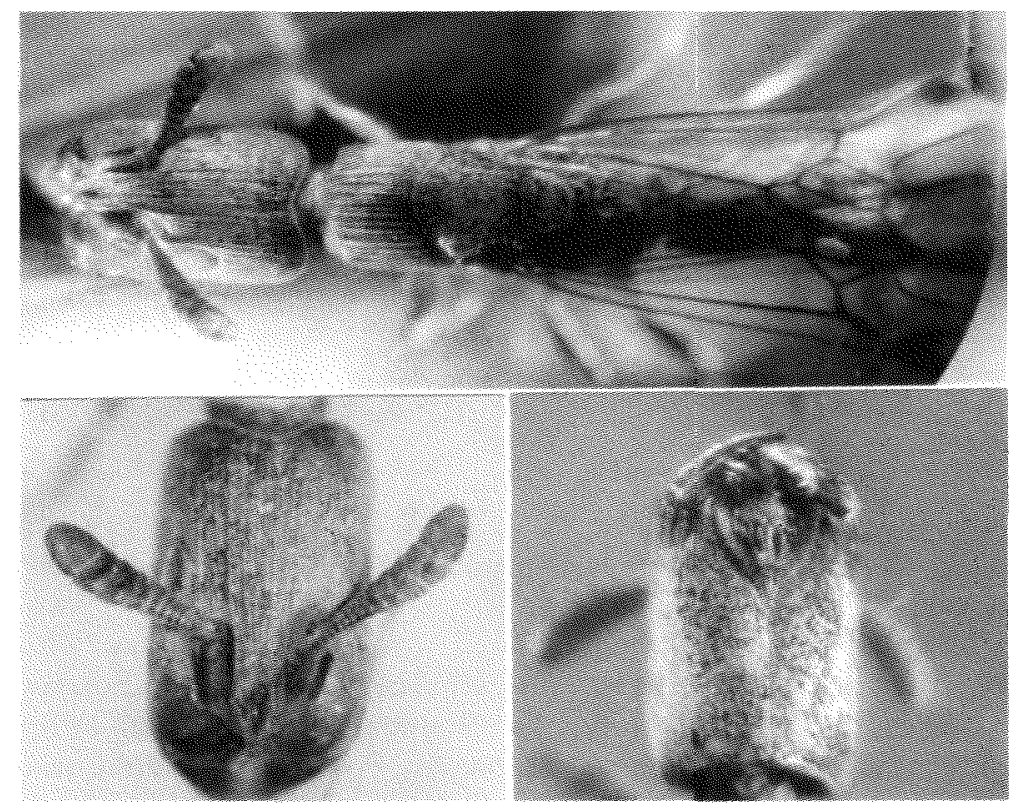

Fig. 1: Specimen H-10-138 B. Dorsal view (top), head in frontal view (bottom left) and head in ventral view (bottom right) to show the broad hypostomal bridge and its short Y-shape .

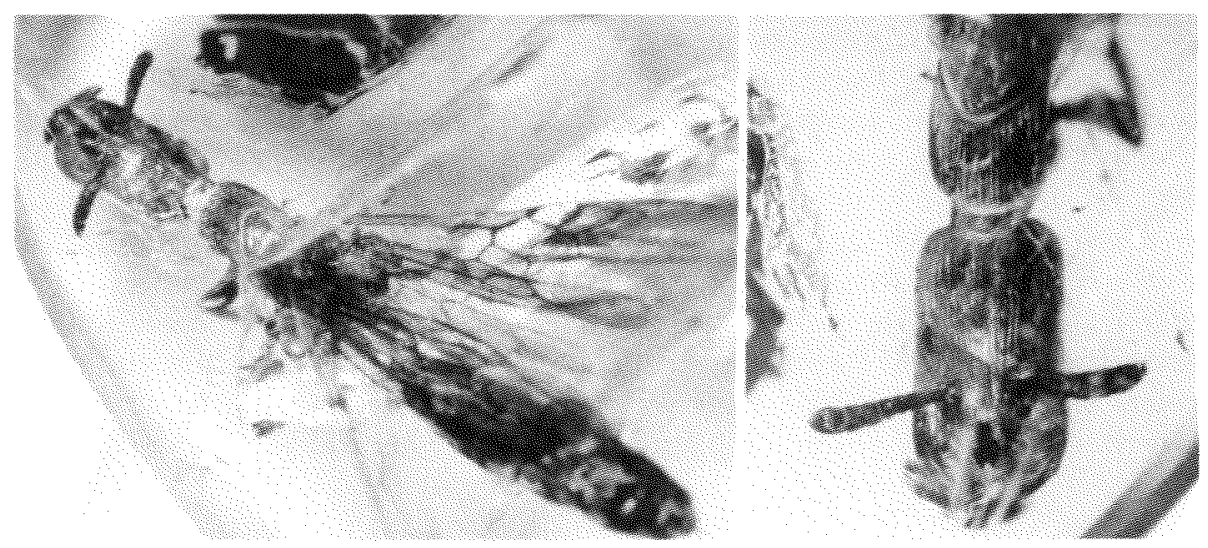

Fig. 2: Specimen H-10-138 C. Dorsal view (left) and head in frontal view (right). 
Parapsidal furrows superficially impressed. Basal face of the propodeum about twice as long as the declivous one and separated each other by a superficial margin. Propleurae slightly concave.

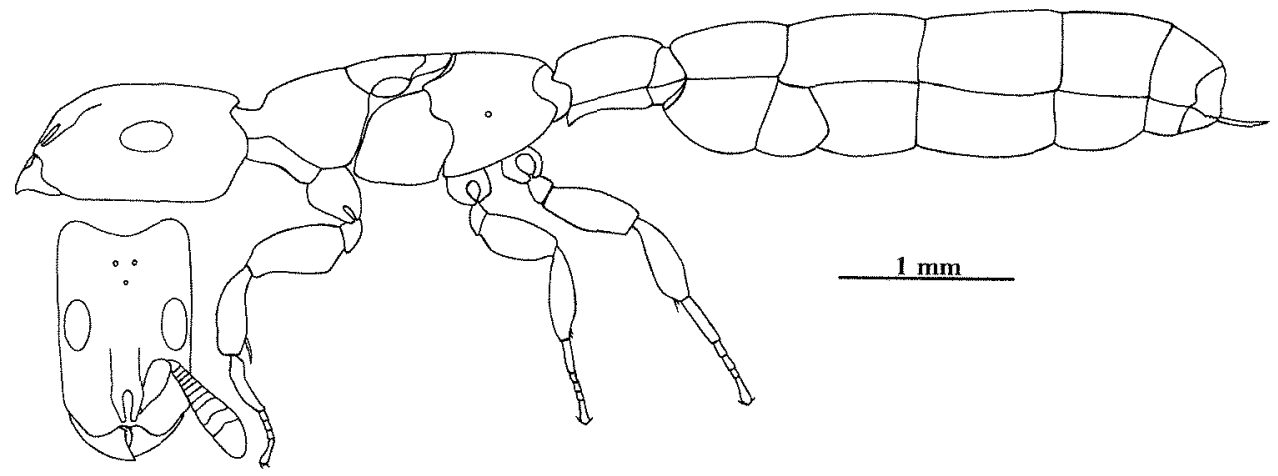

Fig. 3: Cylindromymex inopinatus sp. n. gyne, body in profile (top), head in frontal view (bottom).

Petiole almost 1/5 longer than broad. Anterior face of the petiole short and concave. Ventral process of the petiole anterior, small and pointed. Postpetiole broader than long. Postpetiolar sides gently diverging posteriorly. Postpetiolar sternite antero-medially with a poorly marked subtriangular "lip". Pygidium truncate; its border with a semicircle of small denticles.

Femora and tibiae inflate. Hind basitarsi ca.1/3 shorter than the maximum length of the hind tibiae. Outer apical edge of the hind and of the mid basitarsi respectively with 5 and 6 spine-like setae each.

Wings similar to those of boliviae (DE ANDRADE, 1998, Fig. 4).

Sculpture. Head dorsum covered by thin longitudinal striae, more superficial and thinner close to the antennal scrobes. Ventral part of the head with longitudinal striae, fainter on the posterior half, absent on the centre, covered by punctuation only. Mesosoma with longitudinal striae thicker on the pronotum. Pronotum with 22-26 longitudinal striae thicker than those on the posterior half of the head dorsum. Pleurae and petiolar sides with longitudinal striae similar to those on the antennal scrobes. Petiolar dorsum with 19-20 striae slightly thinner than those on the pronotum. Declivous face of the propodeum and anterior face of the petiole minutely punctate. Dorsum of the postpetiole with striae slightly thinner than on the petiole. First gastric tergite covered by striae thinner than those on the postpetiole. Second gastric tergite with thin and superficial striae on the center only. Remaining gastric tergites and sternites sparsely and minutely reticulate and densely punctate. Legs with very superficial, minute punctures. Ventral face of the coxae covered by thin longitudinal striae, thinner and less marked on the fore coxae.

Pilosity. Body with pointed hairs of at least three differentiable lengths and distributed as follows: (1) long, erect to suberect, one pair on the clypeus, one on each antennal scape, one close to each pronotal angle, tare on the gaster, sparse on the pygidium; (2) 


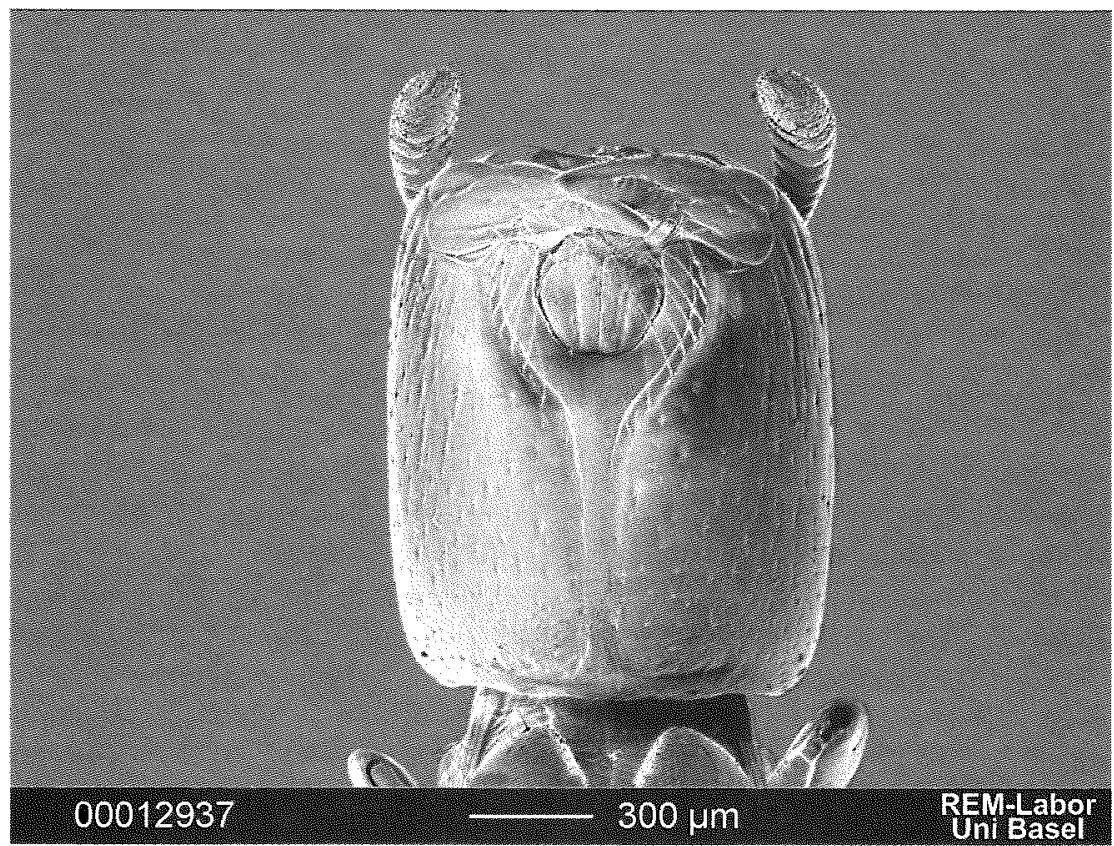

Fig. 4: Cylindromymex longiceps AnDRE. Gyne from Porto Seguro, Bahia, Brazil. Head in ventral view to show the broad hypostomal bridge and its Y-shape.

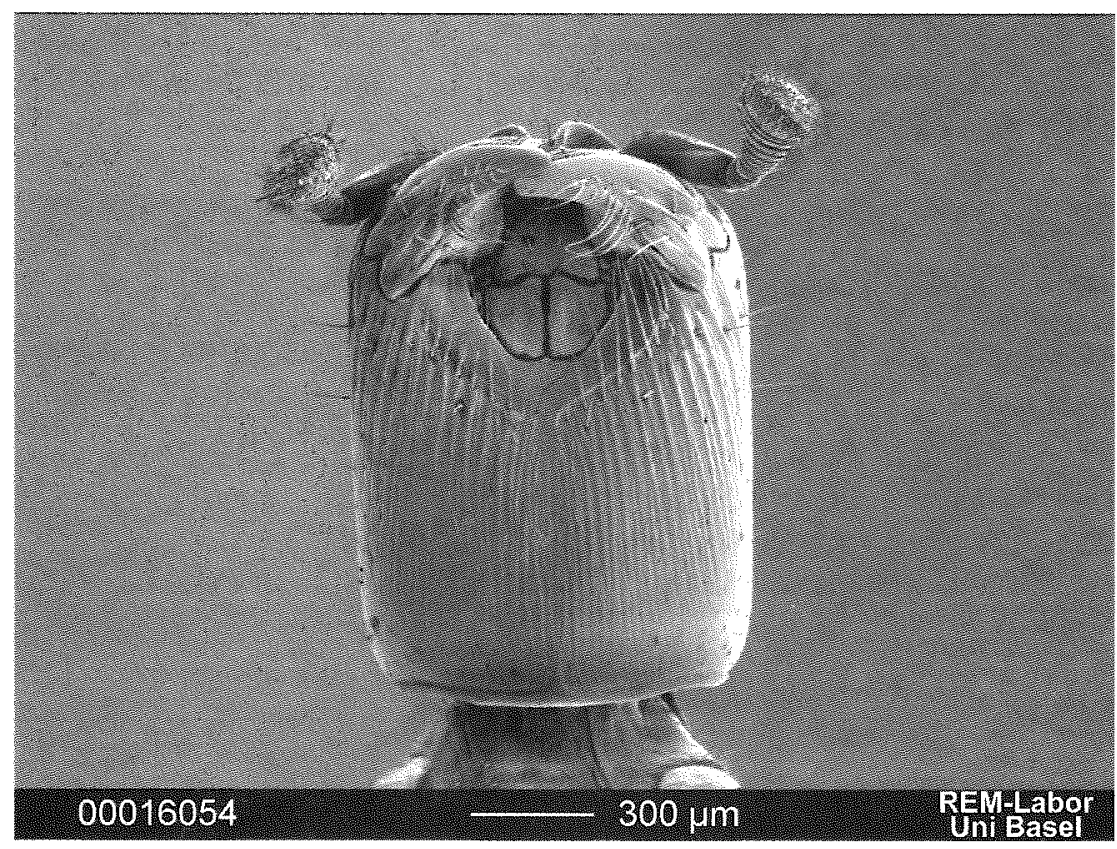

Fig. 5: Cylindromyrmex meinerti ForEL. Gyne from Costa Rica, Heredia, Est. Biol. La Selva. Head in ventral view to show the broad hypostomal bridge and its U-shape. 
shorter than the type (1) and sparsely distributed on the whole body; (3) shorter than type (2), sparse and suberect on the head dorsum and on the mesosoma, sparse and subdecumbent on the pedicel, on the gaster and on the legs. In addition the hypostomal bridge is surrounded by a layer of hairs similar to the type (1). Colour black.

Measurements (in $\mathrm{mm}$ ) and indices: TL 6.93 (holotype), 3.99 (paratype without gaster); HL 1.12-1.30; HW 0.76-0.82; EL 0.31; SL 0.33-0.36; SW 0.13-0.14; WL 1.72-1.64; PeL 0.56-0.57; PeW 0.46-0.47; HFeL 0.50; HFeW 0.25; HTiL 0.52-0.53; HTiW 0.18-0.19; HBaL 0.30-0.36; HBaWr 0.07-0.08; CI 63.1-67.8; SI 38.9-39.4; HFeI 50.0; HTiI 34.6-35.8; HBaI 22.2-23.3.

\section{Discussion}

In the phylogeny proposed by DE ANDRADE (1998) C. longiceps results as the sister species of meinerti. The new species described above, however, finds its optimal position between the two and is, hence, the new sister species of longiceps.

C. inopinatus possesses both synapomorphies previously shared by longiceps and meinerti, i.e., the highest values of HFeI (Hind Femora Index 50) and the broad hypostomal bridge. In addition, $C$. longiceps shares with inopinatus only the mid basitarsi longer than $1 / 2$ of the hind basitarsi a previous autapomorphy for longiceps. At least another, new synapomorphy for longiceps and inopinatus could be added to the data matrix used by DE ANDRADE (1998) to infer her phylogeny: longiceps and inopinatus are the sole species sharing flat mandibles with almost edentate margin. Other potential synapomorphies for these two species are the frontal carinae much shorter than the anterior border of the clypeus and the reduced ventral process of the petiole. I refrain, however, from adding these characters to the original data matrix because they re-appear in an unpredictable way among other species of the genus.

It is worth recalling that the connection of the hypostomal bridge to the postocciput in C. inopinatus shows an intermediate condition between the one of C. longiceps and C. meinerti (Figs. 1 bottom right, 4 and 5).

New locality records

\section{Cylindromyrmex brasiliensis EMERY}

Fig. 6

BRAZIL: BAHIA: Porto Seguro, 4.XI.1997, 1 male, JRMS \& HJS [CPCC].

This male differs from the previously known male from Santa Catarina (DE ANDRADE, 1998) in the following: size smaller (see measurements below), body striae thinner, body foveae less impressed, metapleurae irregularly striate-foveolate.

Male, measurements (in mm) and indices: TL 7.20-8.78; HL 1.04-1.16; HW 1.00-1.16; EL 0.51-0.59; SL 0.27-0.32; SW 0.15-0.17; WL 2.32-2.76; PeL 0.75-0.81; PeW 0.58-0.72; HFeL 0.86-1.00; HFeW 0.210.23; HTiL 0.76-0.88; HTiW 0.16-0.18; HBaL 0.64-0.77; HBaW 0.06-0.07; CI 96.1-100.0; SI 53.1-55.5; HFeI 23.0-24.4; HTiI 20.4-21.0; HBaI 9.4-10.4.

\section{Cylindromyrmex brevitarsus SANTSCHI}

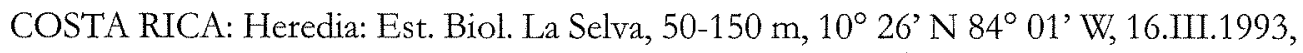
1 gyne, INBio-OET [INBC]. ECUADOR: SuCuMBIOS: $0.5^{\circ} \mathrm{S} 76.5^{\circ} \mathrm{W}$, Sacha Lodge, 290 m, 22.II-4.III.1994, 1 gyne, 1 male, P. Hibbs [LACM]. BRAZIL: BAHIA: Porto Segu- 
ro, 30.VIII. 1997, 23.IX.1997, 25.X.1997, 8.XI.1997, 2.XII.1997, 7 males, JRMS \& HJS [CPCC]; same locality, 4.XI.1997, 11.XI.1997, 6 males, JRM Santos [CPCC]. As already noted by DE ANDRADE (1998) separation between this species and the Cuban endemic darlingtoni relies largely on the geographic insulation of the latter. The material studied for the present paper does not help solving the problem of the specific value of darlingtoni. To do this, however, more Cuban material would be necessary.

\section{Cylindromyrmex escobari DE ANDRADE}

COSTA RICA: Province Puntarenas, Monteverde, $1500 \mathrm{~m}, 18 . \mathrm{II} .1989,1$ gyne, B. Fisher [INBC]. This species was described by DE ANDRADE (1998) and known only on the holotype worker from Colombia. The gyne from Costa Rica was figured and described by LONGINO (1999). The gyne is larger than the worker and its measurements and indices are the following:

Gyne, measurements (in mm) and indices: TL 9.74; HL 1.64; HW 1.32; EL 0.50; SL 0.71; SW 0.24; WL 2.84; PeL 0.94; PeW 0.80; HFeL 1.03; HFeW 0.41; HTiL 0.86; HTiW 0.28; HBaL 0.52; HBaW 0.10; CI 80.5; SI 33.8; HFeI 39.8; HTil 32.5; HBaI 19.2.

\section{Cylindromyrmex godmani FOREL}

COSTA RICA: Guanacaste, Volcán Cacao, Cerro Pedregal, 1000 m, II-IV.1989, 1 male, I. Gauld [INBC]; Limón, 16 km W Guápiles, 400m, VIII-IX.1989, 1 gyne, P. Hanson [INBC]. This species is known on a few specimens only. The gyne from Costa Rica differs from the holotype from Panama mainly by the smaller size (see measurements below).

Gyne, measurements (in mm) and indices: TL 12.20-14.38; HL 2.04-2.18; HW 1.44-1.54; EL 0.58-0.64; SL 0.75-0.82; SW 0.29-0.31; WL 3.56-4.04; PeL 1.16; PeW 0.96-1.00; HFeL 1.08-1.16; HFeW 0.44-0.49; HTiL 0.90-1.00; HTiW 0.33-0.39; HBaL 0.66-0.71; HBaW 0.13-0.14; CI 70.6; SI 37.8-38.6; HFeI 40.7-42.2; H'TiI 36.7-39.0; HBaI 19.7 .

\section{Cylindromyrmex longiceps ANDRÉ}

Figs. 4 \& 7

Male (previously undescribed) (Fig. 7). Head longer than broad. Vertexal margin convex. Ocelli protuberant. Compound eyes broadly convex and largely on the anterior part of the head. Frontal carinae with slightly raised borders and partially covering the antennal socket. Sides of the frontal carinae subparallel anteriorly, slightly diverging and broadly separate posteriorly. Frons concave anteriorly, strongly raised medially and declivous posteriorly. Anterior border of the clypeus straight. Mandibles relatively short, thin, with the base of the external border gently impressed. Masticatory margin of the mandibles with a small basal tooth followed by an edentate margin and a pointed apical tooth. Scapes about $1 / 3$ longer than broad. Funicular joints stout.

Mesosoma elongate. Pronotum in dorsal view with subparallel sides. Scutellum about as high as the mesonotum. Parapsidal furrows superficially impressed. Basal face of the propodeum separate from the declivous one by a marked carina.

Petiole subcylindric; anterior face short and concave, dorsal face gently convex. Ventral process of the petiole small and subtriangular. Postpetiole broadening backwards, slightly shorter and less broad than the first gastric tergite. 


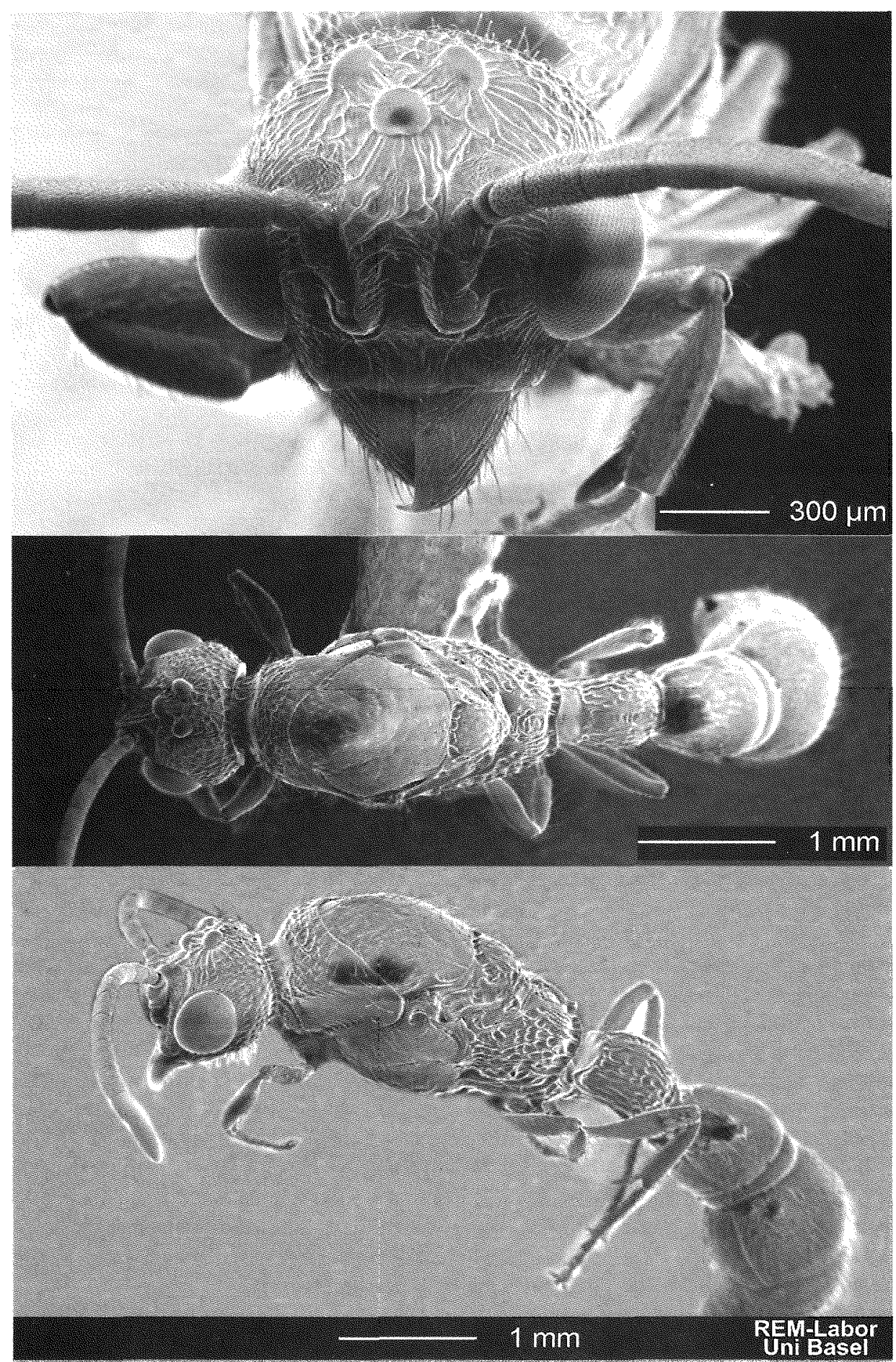

Fig. 6: Cylindromyrmex brasiliensis EMERY. Male from Porto Seguro, Bahia, Brazil. Head in dorsal view (top), body in dorsal view (middle), body in profile (bottom). 


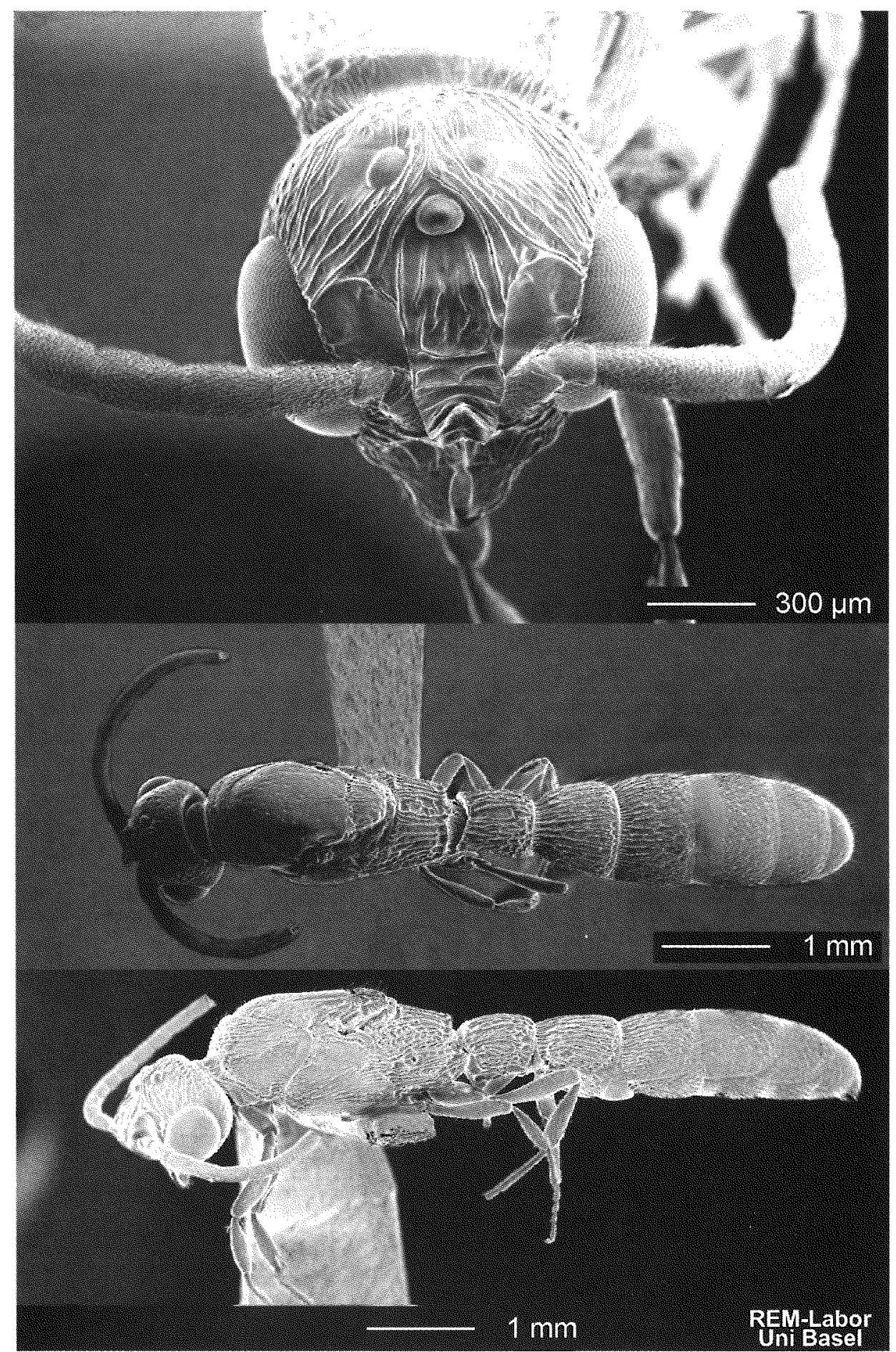

Fig. 7: Gylindromyrmex longiceps ANDRÉ. Male from Porto Seguro, Bahia, Brazil. Head in dorsal view (top), body in dorsal view (middle), body in profile (bottom). 
Genitalia not dissected. Distal half of the hypopygium visible. Apodemes of the subgenital plate similar to those of meinerti (DE ANDRADE, 1998, Fig. 34 B) and median projection between the apodemes similar to the one of godmani (DE ANDRADE, 1998, Fig. 27 B) but less pointed.

Femora not inflate. Mid and hind basitarsi long.

Wings similar to those of godmani (DE ANDRADE,1998, Fig. 5).

Sculpture. Head dorsum covered by striae converging from the internal border of the eyes to the ocelli; striae between the pair ocelli longitudinal. Frons with irregular striae, transversal anteriorly and longitudinal posteriorly. Area between the vertexal border and the eyes with small foveae. Ventral part of the head variably punctate and with piligerous foveae fainter posteriorly; antero-ventral part of the head with additional transversal, thin, striae between the piligerous foveae. Pronotum irregularly foveolate-striate on the center and with slightly longitudinal striae on the sides. Mesonotum smooth, with small, sparse piligetous foveae. Scutellum sculptured as the mesonotum but with few additional, thin, longitudinal rugosities. Basal face of the propodeum, metapleurae, petiole, postpetiole, first gastric tergite and postpetiolar sternite with irregular longitudinal striae and foveae; this sculpture more superficial and sparser on the postpetiolar sternite. Declivous face of the propodeum punctate and with longitudinal striae. Pro- and mesopleurae superficially punctate, with thin, short longitudinal striae and small piligerous foveae; the punctures and striae rare on the center of the mesopleurae. Remaining gastral segments punctate and with superficial piligerous foveae.

Pilosity. Body covered mainly by pointed hairs of three types: (1) long, rare on the head, sparse and subdecumbent on the mesosoma, on the petiole, on the postpetiole, on the first gastric tergite, and on the legs, dense and appressed on the remaining gastral tergites and on all sternites; (2) shorter than type (1), sparse on the head, on the mesosoma, dense and mixed with hair type (1) on the second and on the remaining gastric tergites and on all sternites and on the legs; (3) short and thick on the funicular joints.

Colour. Black. Mandibles, coxae and antennal club dark brown. Legs, scapes and first funicular joints light brown.

Male, measurements (in mm) and indices: TL 6.44; HL 1.08; HW 0.92; EL 0.60; SL 0.23; SW 0.14; WL 1.40; PeL 0.65; PeW 0.62; HFeL 0.80; HFeW 0.20; HTiL 0.72; HTiW 0.18; HBaL 0.61; HBaW 0.06; CI 85.2; SI 60.7 ; HFeI 25.0; HTiI 25.0; HBaI 9.84.

BRAZIL: BAHIA: Porto Seguro, 4.XI.1997, 1 male, JRMS \& HJS [CPCC]; Porto Seguro, 2.XII.1997, 1 gyne, JRMS \& HJS [CPCC].

Note: The Bahian gyne of longiceps differs from the unique previously known gyne from São Paulo described by KEMPF (1968) and by DE ANDRADE (1998) in the following details: size smaller (see measurements below) and number of striae on the pronotum 18 instead of 28 . It is worth mentioning that some workers of C. longiceps from Rio de Janeiro are also larger (TL 7.44-8.50 mm) than the gyne from Bahia (TL 7.90 $\mathrm{mm})$.

Gyne, measurements (in mm) and indices: TL 7.90-9.94; HL 1.46-1.84; HW 1.02-1.18; EL 0.45-0.54; SL 0.45-0.49; SW 0.20 0.21; WL 2.12-2.76; PeL 0.68-0.74; PeW 0.70-0.76; HFeL 0.63-0.73; HFeW 0.320.38; HTiL 0.67-0.75; HTiW 0.24-0.27; HBaL 0.43-0.44; HBaW 0.11; CI 64.1-70.0; SI 42.8-44.4; HFeI 50.852.0; HTiI 35.8-36.0; HBaI 25.0-25.6. 


\section{Cylindromyrmex meinerti FOREL}

Fig. 5

COSTA RICA: Puntarenas, Golfo Dulce, $24 \mathrm{~km}$ W Piedras Blancas, $200 \mathrm{~m}$, XII.1989III.1990, 1 male, Hanson [INBC]; Puntarenas, Golfo Dulce, $3 \mathrm{~km}$ SW Rincón, 10 m, IIIII.1989, 1 gyne, Hanson [INBC]; Puntarenas, Peninsula Osa, Rancho Quemado, 270 m, I.1991, 1 male, P. Hanson [INBC]; Guanacaste, Cerro El Hacha, NW Volcán Orosi, 300 m, 1988, 1 gyne, [INBC]; Heredia, Est. Biol. La Selva, 50-150 m, 10²6' N 8401' W, 1 gyne, 15.III.1993 [INBC].

\section{Cylindromyrmex whymperi (CAMERON)}

COSTA RICA: Heredia Province: La Selva Biol. Station $3 \mathrm{~km}$ S Pto. Viejo, $10^{\circ} 26^{\prime} \mathrm{N} 84^{\circ}$ 01' W, 10.VIII.1996, 1 worker, H. A. Hespenheide [INBC]; same locality, VII.1992, 50150 m, 2 workers, J. Longino [INBC]; Guanacaste, sotobosque, W side Volcán Cacao, 1100 m, II.1989, 1 worker, I. Gauld [INBC]; Guanacaste, Arenales, W side Volcán Cacao, 900 m, 1988-1989, 1 worker [INBC]; Cartago Province, Turrialba, Catie, 25.V.1995, 1 gyne, J. Rifkind [LACM]. COLOMBIA: VALLE: Hacienda las Pilas, 9.IV.1999, 1 worker, F. Lozano [MEUV].

\section{Identification keys}

A printing mistake occurred in the first two couplets of the identification key for the workers. The numeration of the second description in each must be corrected as follows:

\section{Workers}

- Eyes small or of medium size (>16 and <200 ommatidia) ..... (4) [erroneously given as 3]

- Legs dark ferrugineous to black

(3) [erroneously given as 4]

Trying to identify the new species inopinatus by means of the key proposed by DE ANDRADE (1998) leads to its sister species, longiceps from which inopinatus can be easily separated by the characters already given, $i$. e. shorter hypostomal bridge, smaller size, etc. as already detailed in the description.

In order to add the male of $C$. longiceps, described in this paper, it was necessary to reelaborate the identification key to the males of DE ANDRADE (1998).

Males of $C$. darlingtoni do appear to have been already collected and were offered to me for study by Dr. Jorge Luis Fontenla Rizo. Two successive requests of this material to Dr. Fontenla Rizo remained unanswered. 


\section{Males}

1. Frontal carinae strongly converging and almost touching each other posteriorly and broadly separated anteriorly (Figs. 26, 33 of DE ANDRADE 1998)

Frontal carinae not strongly converging posteriorly (Figs. 6, 7, 10, 15, 22 of DE ANDRADE 1998), if almost touching each other posteriorly (few males of brevitarsus) then never broadly separated anteriorly.

2. Total length (TL) $>9.5 \mathrm{~cm}$. Mesosoma massive. Petiole with traces of striae anteriorly only. Postpetiole smooth. Costa Rica, Panama, Ecuador.... godmani

- Total length (TL) $<8.5 \mathrm{~cm}$. Mesosoma elongate. Petiole entirely striate. Postpetiole superficially striate. Costa Rica, Panama, Venezuela, Brazil ...... meinerti

3. Hypopygium smooth, finely denticulate or with a simple median projection between the distal apodemes (Figs. 7B, 11B, 13B, 27B of DE ANDRADE 1998)

Hypopygium with a bidentate median projection between the apodemes (Figs. $16 \mathrm{~B}, 23 \mathrm{~B}, 24 \mathrm{~B}$ of DE ANDRADE 1998)

4. Postpetiole and first gastric tergite sculptured. Masticatory margin of the mandibles with a basal tooth. $\mathrm{CI}=85.2$. Hypopygium with a simple median projection between the distal apodemes. Brazil longiceps Postpetiole and first gastric tergite smooth. Masticatory margin of the mandibles without a basal tooth. CI $>95.2$

5. Anterior clypeal border slightly convex (Fig. 6). Hypopygium finely denticulate between the distal apodemes (Fig. 7B of DE ANDRADE 1998). Brazil and Paraguay . brasiliensis

- Anterior clypeal border straight (Fig. 10 of DE ANDRADE 1998). Hypopygium smooth between the distal apodemes. (Figs. 11B, 13B of DE ANDRADE 1998) Guatemala, Costa Rica, Colombia, Galapagos Island, Ecuador, Peru, Bolivia, Chile, Brazil whymperi

Surinam, French Guyana, Brazil striatus

6. Coxae black with the remaining parts of the legs yellow to light brown. Ventral border ofthe aedeagus with at least 42 denticles. Costa Rica, Venezuela, Ecuador, Peru and Brazil brevitarsus

Coxae dark or black, concolour with the remaining parts of the legs. Ventral border of the aedeagus with at most 32 denticles. Colombia, Venezuela, Peru and Bolivia boliviae

\section{Acknowledgements}

I would like to express my watmest thanks to CESARE BARONI URBANI for the suggestions and helps during this study. I am grateful to the persons who send material in study. Particular warm acknowledgements are due to DANIEL MATHYS and MARCEL DOGGEIIN for the help at the Centre of Scanning Electron Microscopy of the Basel Uniyersity. 


\section{References}

ANDRADE, M. L. (DE) 1998: Fossil and extant species of Gylindromymmex (Hymenoptera: Formicidae). - Revue suisse de Zoologie 105 (3): 581-664.

KEMPF, W. W. 1968: Miscellaneous studies on Neotropical ants. IV. (Hymenoptera: Formicidae). - Studia Entomologica 11: 369-415.

LONGINO, J. T. 1999: Ants of Costa Rica. - 10 pp.

http://www.evergreen.edu/user/serv_res/research/arthropod/genera/Cylindromyrmex/specieslist.html. World Wide Web document.

\section{Authors' address:}

Dr. MARIA L. DE ANDRADE

Institut für Natur-, Landschafts- und Umweltschutz

Universität Basel

Neuhausstrasse 31

$\mathrm{CH}-4057$ Basel

Switzerland

\section{Besprechungen}

HECQ, J: Tagfalter. Teil 9: Nymphalidae IV, Bebearia. - Keltern: Goecke \& Evers, 2000. - 7 S., 32 Farbtaf. - (Schmetterlinge der Erde / BAUER, E. \& FRANKENBACH, T. [Hrsg.]). - (ISBN 3-931374-76-9); Englische Ausgabe unter dem Titel: Butterflies of the world. Part 9. Nymphalidae IV, Bebearia. - Keltern: Goecke \& Evers, 2000 (ISBN 3-931374-77-7); Canterbury: Hillside Books (ISBN 1-903237-02-5).

Winhard, W: Tagfalter. Teil 10: Pieridae I, Text, Tafeln. - Keltern: Goecke \& Evers, 2000. - 40 S., 48 Farbtaf. - (Schmetterlinge der Erde / BAUER, E. \& FrANKENBACH, T. [Htsg.]) - (ISBN 3-931374-78-5); Englische Ausgabe unter dem Titel: Butterflies of the world. Part 10. Pieridae I, text, plates. - Keltern: Goecke \& Evers, 2000 (ISBN 3-931374-79-3); Canterbury: Hillside Books (ISBN 1-903237-05-X).

LukHtanov, V. A. \& EITSChBerger, U. F. J.: Tagfalter. Teil 11: Nymphalidae V, Oeneis. - Keltern: Goecke \& Evers, 2000. - 12 S., 28 Farbtaf. - (Schmetterlinge der Erde / BAUER, E. \& FRANKENBACH, T. [Hrsg.]) - (ISBN 3-931374-80-7); Englische Ausgabe unter dem Titel: Butterflies of the world. Part 11. Nymphalidae V, Oeneis. - Keltern: Goecke \& Evers, 2000 (ISBN 3-931374-81-5); Canterbury: Hillside Books (ISBN 1-903237-06-5).

Auch im Jahr 2000 kann hier das Erscheinen weiterer Teile der Serie angezeigt werden.

Die Bearbeitung der Nymphalidae wird mit det über die Gattungen Bebearia HEMMING, Oeneis HÜBNER. und Davidina OBERTHUR fortgesetzt. Eine wichtige Ergänzung zur Bearbeitung der Gattung Bebearia (Abbildung von 90 Arten und zahlreichen Unterarten) ist der in Supplement 3 dieser Serie erschienene französische Text von HECQ, J.: Le genre Bebearia (34 p.). Die Bearbeitung der Gattung Oeneis umfaßt die Darstellung von 32 Arten mit zahlreichen subspezifischen Taxa, darunter auch Neubeschreibungen neuer Unterarten. Die Tafeln zeigen von allen Taxa beide Geschlechter sowie Ober- und Unterseite. Die Vorlagen für die Abbildungen befinden sich in der Mehrzahl in der Sammlung U. EITSCHBERGER/ Markleuthen (EMEM). Auch zu diesem Teil ist als Supplement 4 ein ausführlicher Text in englischer Sprache in Vorbereitung.

Mit Teil 10 beginnt die Bearbeitung der Pieridae. In vorliegendem Teil sind auf 837 Abbildungen 505 der bisher etwa 1200 bekannten Arten abgebildet. Hauptquelle der Abbildungsvorlagen war die Sammlung EDUARD REISSINGER, die sich im Staatlichen Museum für Naturkunde Stuttgart befindet. Weiteres Material stammt aus der Sammlung des Bearbeiters sowie aus der der Zoologischen Staatssammlung München. 